\title{
Persistent infertility in ewes after prolonged exposure to oestradiol-17及
}

\author{
N. R. Adams and M. R. Sanders \\ CSIRO Division of Animal Production, P.O., Wembley, Western Australia 6014, \\ Australia
}

\begin{abstract}
Summary. Merino ewes were treated with implants which released $300 \mu \mathrm{g}$ oestradiol$17 \beta$ per day or $5 \mathrm{mg}$ progesterone per day, or both, for 9 months (Months 1-9), and after an 11-month intermission were treated again for 6 months (Months 20-26). Ewes were run with rams at Months 16, 28 and 40. Fertility was not affected by the first exposure period, but the second exposure to oestradiol reduced the fertility of ewes at both subsequent mating periods. Affected ewes returned to service more frequently $(P<0.01)$ and were less likely to conceive $(P<0.05)$. After mating, a normal population of spermatozoa was established in the caudal cervix, but transport through the cervix was impaired in affected ewes and there were fewer spermatozoa $(P<0.01)$ in the cranial cervix. In affected ewes, the spinnbarkeit of cervical mucus was reduced $(P<0.05)$, and the histological appearance of the cervix changed, looking like that of the uterus. Treatment with progesterone did not affect fertility, cervical mucus or sperm transport, but diminished the histological abnormalities produced by oestradiol $(P<0.05)$.

These results show that oestradiol-17 $\beta$ given after puberty can cause the same kind of permanent sexual transdifferentiation that is produced by the oestrogenic isoflavones in ewes with clover disease. The results suggest that this change may require more than a single exposure to oestrogen.
\end{abstract}

Keywords: oestradiol; infertility; ewes; transdifferentiation; cervix

\section{Introduction}

Females of most mammalian species become infertile when treated with oestrogen, but their fertility is normally restored when treatment ceases. However, prolonged exposure of ewes to oestrogenic isoflavone compounds causes an infertility from which the animals may never recover (Schinckel, 1948). This permanent infertility can form part of the syndrome called "clover disease" (Bennetts et al., 1946). Repeated injection with diethylstilboestrol produces an apparently similar syndrome (Underwood et al., 1959), but permanent infertility has not been reported in animals exposed to oestrogenic coumestan or steroid compounds.

The permanent infertility in clover disease results from a failure of the ewes to establish a normal population of spermatozoa in the cervix after mating (Lightfoot et al., 1967). The cervical malfunction is associated with a reduced spinnbarkeit (capacity to be drawn into threads) in the cervical mucus (Adams, 1976) and a change in the histological structure so that the cervical architecture and cells appear more like endometrium (Heydon \& Adams, 1977). These changes occur as part of a general sexual transdifferentiation in affected ewes (Adams \& Tang, 1986), and are accompanied by slight defeminization and masculinization of sexual behaviour (Adams, 1983) and an impairment of the sex-dependent mechanism controlling the preovulatory surge of LH (Adams \& Martin, 1983). 
Such sexual transdifferentiation is most unusual in adult mammals, and the question arises as to whether it is an aberrant response to oestrogenic isoflavones, or whether it can also be produced by a more physiological oestrogen such as oestradiol-17 $\beta$. In the present study, therefore, adult ewes were exposed to oestradiol-17 $\beta$ for a prolonged period and examined for the functional abnormalities which have been reported in ewes with clover disease.

\section{Materials and Methods}

Peppin Merino ewes, 2 years of age, which had not been exposed to oestrogenic subterranean clover were divided into 4 groups of 20 , and fitted subcutaneously with empty implants (controls) or implants releasing oestradiol-17\%, progesterone or both. The implants were made by packing Silastic tubing (Dow Corning Corp., Midland, MI, U.S.A.) with oestradiol- $17 \beta$ (i.d. $3.35 \mathrm{~mm}$, o.d. $4.65 \mathrm{~mm}$, length $60 \mathrm{~mm}$ ) or progesterone (i.d. $6.35 \mathrm{~mm}$, o.d. $9.52 \mathrm{~mm}$, length $80 \mathrm{~mm}$ ) and sealing the ends. The release rates of the implants were estimated, using tritiated steroid in vitro, to be $300 \mu \mathrm{g}$ oestradiol or $5 \mathrm{mg}$ progesterone per $24 \mathrm{~h}$.

The design of the study can be seen in Fig. 1. Ewes were given implants initially for 9 months (Months 1-9). After 7 months (Month 16), the ewes were mated for 8 weeks and, at 2 months after mating (Month 20), the ewes were given similar implants for a further 6 months. These implants were removed at the time that the ewes' lambs were weaned (Month 26). The ewes were run with rams 2 months later (Month 28) and again 14 months (Month 40) after the implants were removed.

Two rams fitted with harnesses and crayons were used. Service records were determined by changing the crayon colour every 2 weeks and recording the marks. Lambing data were recorded using the criteria of Dun (1963).

At 6 months after the final lambing, a commercial progesterone implant (Silestrus: Abbott Labs, Eastwood, NSW, Australia) was used to synchronize oestrus in all ewes. Vasectomized rams were fitted with crayons and with aprons to prevent intromission, and were run with the ewes. The ewes were inspected twice daily and, when they were first marked by the ram, samples of cervical mucus were collected, weighed and examined for spinnbarkeit as described previously (Adams, 1976).

The aprons were then removed from the vasectomized rams, and the crayons changed. At the expected time of the next oestrus, the ewes were inspected daily at $07: 00$ and $18: 00 \mathrm{~h}$ and, when detected in oestrus, they were removed and mated once with each of 3 rams drawn from a group of 6 . These rams all produced semen with a strong wave motion, high motility and an average of $4.6 \pm 2.3 \times 10^{9}$ spermatozoa $/ \mathrm{ml}$.

At $24 \mathrm{~h}$ after mating, the ewes were killed by an overdose of pentobarbitone. The abdominal cavity was opened, a clamp was placed on the utero-cervical junction and the reproductive tract was removed onto ice. The cervix was removed and divided into three equal pieces. The middle third was fixed in formol-buffered saline for histology, while the cranial and caudal pieces were each cut into longitudinal strips, and shaken for $30 \mathrm{~min}$ in $\mathrm{Ca}^{2+}$-free $\mathrm{Krebs}-\mathrm{Ringer}$ saline, as described by Croker et al. (1975). The tissue was removed, and the numbers of spermatozoa were counted by the method of Mattner \& Braden (1963). Ewes which had not come into oestrus after 4 days were killed by overdose of pentobarbitone, and the cervix fixed in formol-buffered saline. The fixed tissue from all ewes was embedded in paraffin wax, cut histologically and stained with haematoxylin and eosin. The numbers of cervical crypts and crosssections through cervical glands were counted and the area of lamina propria tissue was measured as described previously (Adams, 1986).

Data were subjected to analysis of variance, and individual comparisons were made using the Newman-Keuls test. Values for the numbers of spermatozoa in the cervix, the numbers of glands in the cervix and the weight of cervical mucus were transformed logarithmically to obtain approximate normality of the data. The number of cycles in which ewes were mated by the ram were analysed using Kruskal non-parametric analysis of variance and the proportion of ewes lambing were compared with the $\chi^{2}$ test.

\section{Results}

\section{Fertility}

After the first treatment with steroids for 9 months, there was no significant effect of oestradiol or progesterone on the number of returns to service or the proportion of ewes which conceived and lambed (Year 2, Fig. 1). However, after the second treatment period, both groups of ewes exposed to oestradiol returned to service more often $(P<0.01)$ and fewer of them lambed $(P<0.05)$. Fertility was not affected by progesterone (Fig. 1). The reduced fertility persisted for at least 1 year; in Year 4 both groups of ewes which had previously been treated with oestrogen again returned to the ram more frequently $(P<0.001)$, and had fewer lambs (Fig. 1). 


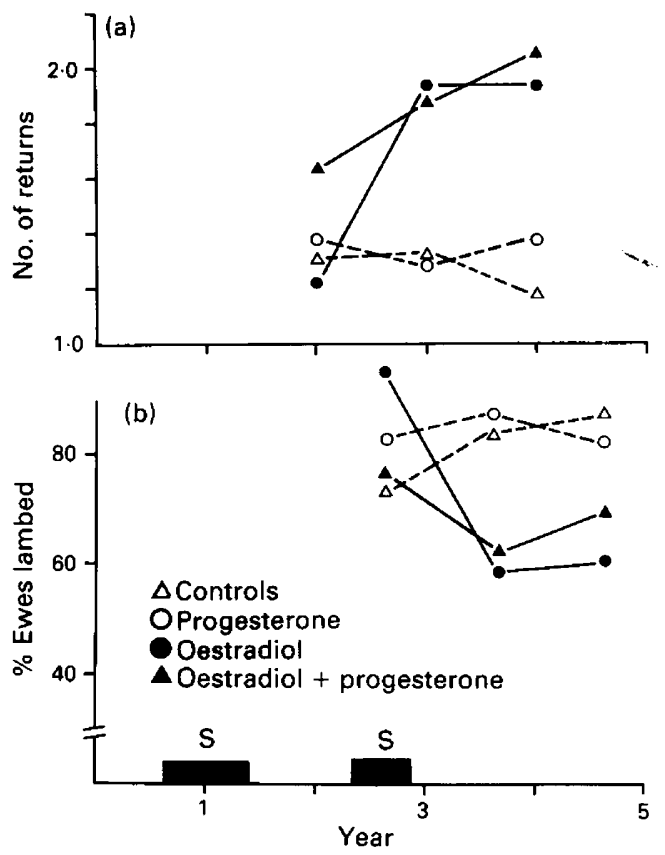

Fig. 1. Effects of treatment with steroids (S) on (a) the average number of cycles in which ewes were mated and (b) the proportion of ewes lambing.

\section{Cervical mucus}

The mean values for spinnbarkeit ( \pm s.e.m.) of the cervical mucus from the control, progesterone, oestradiol and oestradiol + progesterone groups were $13 \cdot 8 \pm 1 \cdot 8,12 \cdot 0 \pm 2 \cdot 1,7 \cdot 9 \pm 1 \cdot 7$ and $9.9 \pm 1.9 \mathrm{~cm}$ respectively. Analysis of variance revealed that treatment with oestradiol reduced spinnbarkeit $(P<0.05)$, but that progesterone had no effect. There were no significant effects of treatment on the weight of mucus recovered.

\section{Sperm transport}

Altogether 32 ewes were observed in oestrus and were mated by the rams (Table 1). Analysis of variance showed that previous treatment with oestrogen reduced the number of spermatozoa in the cranial cervix $(P<0.01)$, regardless of whether the ewes had been treated concurrently with progesterone. Neither oestrogen nor progesterone affected the number of spermatozoa in the caudal cervix (Table 1). The numbers of spermatozoa in the cranial and caudal cervix were correlated $(r=+0.65, \mathrm{~N}=32,(P<0.001)$. When the effect of the number of spermatozoa in the caudal cervix was removed by covariate analysis, the effect of oestrogen was more statistically significant $(P<0.001)$, but no effect of progesterone, or interaction between oestrogen and progesterone treatment was detected.

\section{Morphology}

At slaughter $24 \mathrm{~h}$ after being recorded in oestrus, 10/19 $(53 \%)$ of the ewes which had not been treated with oestradiol had ovulated, compared with $9 / 13(69 \%)$ of the oestradiol-treated ewes.

When all the ewes were considered, visible endometrial cysts were more common in both groups of ewes which had previously been exposed to oestradiol $\left(9 / 19\right.$ vs $\left.3 / 21, \chi^{2}=6.69, P<0.01\right)$ than in 
Table 1. Backtransformed mean and s.e. range for the number of spermatozoa in the cervix of ewes previously treated with steroids

\begin{tabular}{lccc}
\hline & \multirow{2}{*}{$\begin{array}{c}\text { No. of } \\
\text { ewes }\end{array}$} & \multicolumn{2}{c}{ No. of spermatozoa } \\
\cline { 3 - 4 } greatment & mated & Cranial cervix & Caudal cervix \\
\hline $\begin{array}{l}\text { Control } \\
\text { Progesterone }\end{array}$ & 9 & $11900^{\mathrm{a}}(6530-21600)$ & $96800(49800-188000)$ \\
$\begin{array}{l}\text { Oestradiol } \\
\begin{array}{l}\text { Oestradiol }+ \\
\text { progesterone }\end{array}\end{array}$ & 8 & $7110^{\mathrm{a}}(2290-22100)$ & $18400(4980-67800)$ \\
& 5 & $87^{\mathrm{b}}(16-488)$ & $32300(15100-69200)$ \\
\hline
\end{tabular}

Values with different superscripts differ significantly, $P<0.05$.

unexposed ewes. Treatment with progesterone had no effect on macroscopic endometrial cysts. Several of the ewes which were not recorded in oestrus or mated had gross pathological abnormalities of the reproductive tract; 2 of the oestradiol-treated ewes had hydrops uteri, and one had pyometra. In addition, in the group treated with both oestradiol and progesterone, one ewe had pyometra and one ewe had a mummified fetus in the cervix.

The microscopic appearance of the cervix changed after prolonged treatment with oestradiol alone, with an increase in the number of stromal cells in the lamina propria and a tendency for an increase in size (Table 2). Analysis of variance indicated that the overall effect of oestradiol was to reduce the number of cervical crypts $(P<0.001$, Table 2$)$, and to increase the number of crosssections through tubular cervical glands $(P<0.05$, Table 2$)$. Treatment with progesterone had the opposite effects, so that the number of crypts was increased, and the number of glands was reduced $(P<0.05$, Table 2$)$. There was an interaction $(P<0.05)$ between the two steroids on the number of glands (Table 2).

Table 2. Histological characteristics of the cervix of ewes after prolonged treatment with steroids

\begin{tabular}{lcccc}
\hline $\begin{array}{l}\text { Treatment } \\
\text { group }\end{array}$ & $\begin{array}{c}\text { No. of } \\
\text { ewes }\end{array}$ & $\begin{array}{c}\text { Mean no. } \\
\text { of glands } \\
\text { (s.e. range) }\end{array}$ & $\begin{array}{c}\text { No. of } \\
\text { crypts } \\
\text { (mean } \pm \text { s.e.) }\end{array}$ & $\begin{array}{c}\text { Area }\left(\mathrm{mm}^{2} \text { ) of }\right. \\
\text { lamina propria } \\
\text { (mean } \pm \text { s.e.) }\end{array}$ \\
\hline $\begin{array}{l}\text { Control } \\
\text { Progesterone }\end{array}$ & 10 & $213(101-445)^{\mathrm{ab}}$ & $27 \cdot 1 \pm 5.9^{\mathrm{a}}$ & $12 \cdot 4 \pm 1 \cdot 6$ \\
$\begin{array}{l}\text { Oestradiol } \\
\begin{array}{l}\text { Oestradiol }+ \\
\text { progesterone }\end{array}\end{array}$ & 11 & $172(113-262)^{\mathrm{bc}}$ & $34 \cdot 8 \pm 7 \cdot 1^{\mathrm{b}}$ & $12 \cdot 8 \pm 2 \cdot 2$ \\
\hline
\end{tabular}

Values in columns with different superscripts differ significantly, $P<0.05$.

Oestradiol alone produced adenomyosis in the cervix of 6/12 animals, but no adenomyosis was seen in the 8 animals treated concurrently with oestradiol and progesterone $(P<0.05)$, or in any other group.

\section{Discussion}

Prolonged exposure to oestradiol-17 $\beta$ produced persistent infertility in ewes which was essentially similar to the permanent infertility produced by the oestrogenic isoflavone compounds found in clover. Ewes with clover disease fail to conceive and so return to service by the ram, due to impaired 
transport of spermatozoa through the cervix (Lightfoot et al., 1967). This is apparently a result of a reduced spinnbarkeit in cervical mucus (Adams, 1976) and uterine-like transdifferentiation of the cervix (Heydon \& Adams, 1977). All of these abnormalities were seen in ewes treated with oestradiol$17 \beta$ in the present study. Therefore, the changes that have been described in ewes with clover disease are not caused by some toxic effect specific to isoflavones, but are part of a response by the ewe to prolonged stimulation with oestrogens in general.

Progesterone opposed the morphological changes produced by treatment with oestradiol-17 $\beta$ (Table 2), but had no effect on fertility (Fig. 1) or sperm transport. We therefore did not confirm the speculation of Underwood et al. (1959) that concurrent treatment with progesterone might ameliorate the effects of clover disease. However, the in-vitro release rates of the implants suggest that the ratio of progesterone to oestradiol used in the present study was low, relative to the concentrations produced endogenously, or to the oestrogenic activity produced by clover pastures. It is still possible that higher concentrations of progesterone might protect against infertility as well as histological abnormality.

The failure of fertility to decline after the initial treatment with oestradiol was somewhat unexpected, but it is possible that this is a more general phenomenon than previously realized. In the field, fertility is usually normal after exposure to oestrogenic pasture for 1 year, and only begins to decline after exposure for a 2nd year (e.g. Davenport, 1967; Davies et al., 1970). Furthermore, Underwood et al. (1959) found that injection with 10-90 $\mu$ g diethylstilboestrol daily for 6 months produced dystokia in ewes, but it did not significantly affect fertility until a year later. Most of the histological transdifferentiation of the cervix to a uterine-like appearance occurs after treatment with oestrogen has ceased (Adams, 1986; unpublished). It is possible that the permanent abnormality in ewes after prolonged exposure to oestrogen occurs in at least two stages, the first being a 'primary phase' during prolonged exposure to oestrogen, and the second a 'developmental phase' which follows the withdrawal of oestrogen and may require re-exposure.

There is an alternative explanation for the failure of the ewes to become infertile after the initial exposure to oestradiol. The first treatment was administered while the ewes were not pregnant, while the second exposure occurred during late pregnancy and lactation. It is possible that the response to the second exposure resulted from interactions with other hormones secreted during these physiological events. Further studies are needed to examine these possibilities.

In most mammalian species, the genes for oestrogen-directed morphogenesis are switched off after the completion of organogenesis. However, in the ewe they may be re-activated to a slight extent during adult life by plant oestrogens (Adams \& Martin, 1983; Adams \& Tang, 1986), thereby producing permanent infertility. This has normally been considered a pathological process, but the demonstration that similar changes can be produced by oestradiol-17 $\beta$, an endogenous steroid, suggests that some of these effects may be expressed during normal physiological processes. At this stage, we know so little about the manner in which oestrogen brings about these changes, that this question cannot be adequately addressed.

We thank S. Atkinson and J. Abordi for assistance.

\section{References}

Adams, N.R. (1976) Cervical mucus changes in infertile ewes previously exposed to oestrogenic subterranean clover. Res. vet. Sci. 21, 59-63.

Adams, N.R. (1983) Sexual behaviour of ewes with clover disease treated repeatedly with oestradiol benzoate or testosterone propionate after ovariectomy. J. Reprod. Fert. 68, 113-117.

Adams, N.R. (1986) Morphogenic change in the cervix of the ewe after prolonged exposure to oestradiol-17 $\beta$. J. Reprod. Fert. 76, 727-733.

Adams, N.R. \& Martin, G.B. (1983) Effects of oestradiol on plasma concentrations of luteinizing hormone in ovariectomized ewes with clover disease. Aust. J. biol. Sci. 36, 295-303.

Adams, N.R. \& Tang, B.Y. (1986) Changed control of cervical secretion from infertile ewes previously exposed to oestrogenic clover pasture. J. Reprod. Fert. $76,147-152$.

Bennetts, H.W., Underwood, E.J. \& Shier, F.L. (1946) A specific breeding problem of sheep on subterranean clover pastures in Western Australia. Aust. vet. J. 22, 2-12. 
Croker, K.P., Robinson, T.J. \& Shelton, J.N. (1975) The passage of spermatozoa through the cervix of ovariectomized ewes treated with progesterone and oestrogn. J. Reprod. Fert. 43, 405-410.

Davenport, N. (1967) A measure of clover infertility in ewes. J. Agric. West. Aust. 8 (Fourth Series), 83-88.

Davies, H.L., Rossiter, R.C. \& Maller, R. (1970) The effects of different cultivars of subterranean clover ( $T$. subterranean $\mathrm{L}$.) on sheep reproduction in the south-west of Western Australia. Aust. J. agric. Res. $21,359-369$.

Dun, R.B. (1963) Recording the lambing performance of ewes under field conditions. Aust. J. exp. Agric. Anim. Husb. 3, 228-231.

Heydon, R.A. \& Adams, N.R. (1977) Histochemical studies on cervical glands in ewes with clover disease. J. comp. Path. 87, 353-361.
Lightfoot, R.J., Croker K.P. \& Neil, H.G. (1967) Failure of sperm transport in relation to ewe infertility following prolonged grazing in oestrogenic pastures. Aust.J. agric. Res. 18, 755-765.

Mattner, P.E. \& Braden, A.W.H. (1963) Spermatozoa in the genital tract of the ewe. I. Rapidity of transport. Aust. J. biol. Sci. 16, 473-481.

Schinckel, P.G. (1948) Infertility in ewes grazing subterranean clover pastures. Observations on breeding behaviour following transfer to "sound" country. Aust. vet. J. 24, 289-294.

Underwood, E.J., Shier, F.L., Davenport, N. \& Bennetts, H.W. (1959) Further studies on the effects of prolonged injections of stilboestrol on the ewe. Aust. vet. J. 35, 84-87.

Received 29 February 1988 